\title{
Eğitim Kurumlarında Mobbing Uygulamalarına İlişkin Nitel Bir Araştırma
}

\author{
Esen ALTUNAY* \\ Gülşin ORAL ${ }^{* *}$ \\ Münevver YALÇINKAYA***
}

\begin{abstract}
Özet
$\mathrm{Bu}$ araştırmanın amacı, eğitim kurumlarında karşılaşılan mobbing uygulamalarını ve baş etme yöntemlerini ortaya koymaktır. Bu çalışma, mobbing uygulamaları konusunda gerçekçi bir bakış açısı yakalayıp mobbingi önleme konusunda öneriler sunulmaya çalışmaktadır. Araştırmanın evreni, ilköğretim, ortaöğretim ve yükseköğretim kurumlarında görevli olan eğitimcilerdir. Araştırmada, çalışma grubunun belirlenmesinde amaçlı örnekleme yöntemlerinden, ölçüte dayalı örnekleme tekniği dikkate alınmıştır. Araştırmanın çalışma grubundaki katılımcılar, her bir eğitim (ilköğretim, ortaöğretim ve yükseköğretim) kurumu düzeyinden seçilen eğitimcilerdir (öğretmen ve öğretim elemanları). Nitel veri toplama tekniği ele alınan bu araştırmada, yarı yapılandırılmış görüşme tekniği kullanılmıştır. Araştırmada veri toplama aracı olarak araştırmacılar tarafından geliştirilen yarı yapılandırılmış görüşme formu kullanılmıştır. Araştırmada veri toplama aracı olarak geliştirilen görüşme formuna uzman görüşleri doğrultusunda son hali verilmiştir. Bu çalışmada eğitim kurumlarında mobbing uygulamalarına maruz kalan mobbing mağdurlarının durumları belirlenmiş ve mobbing mağdurlarının karşılaştıkları sorunlar incelenmeye çalışılmıştır. Araştırma sonucunda elde edilen temel bulgu, mağdurların, mobbing sürecinin temel noktaları açısından benzer bakış aç1sına, sahip olduklarıdır. Ancak alt temalar açısından mobbing mağdurlarının görüşlerinin çeşitlilik gösterdiği görülmektedir.
\end{abstract}

Anahtar Kelimeler: Mobbing, eğitim kurumları, psikolojik şiddet, mobbing mağduru

\section{A Qualitative Research About Mobbing Implications In Educational Institutions}

\begin{abstract}
The aim of the research is to determine mobbing implications encountering in educational institutions and methods of coping with mobbing. This study tries to make a realistic assessment about practices of mobbing and offers precautions against them. Sampling of research was education institutions. Participants are composed of instructors working in different education institutions. Purposive sampling method is used in the study. Sampling techniques based on the criteria was taken into account for determining of working group. Semi-structure interview is used in this study which covered qualitative data collection techniques. As a data collection tool is used semi-structured interview form developed by researchers. Draft of the semi structured interview form gets the final form through with the expert opinions. In this study, views of victims subject to mobbing implications in educational institutions are identified and problems encountered by these victims in the mobbing process are investigated. The main finding of this study shows that the vi-
\end{abstract}

\footnotetext{
${ }^{*}$ Dr., esenaltunay@yahoo.com

** Öğr. Gör., Dokuz Eylül Üniversitesi, gulsinoral@hotmail.com

*** Prof. Dr., Uluslararası Kıbrıs Üniversitesi-Lefkoşe, myalcinkaya@ciu.edu.tr
} 
ews of victims of mobbing have similarities in terms of the main points of mobbing. However, these views of victims of mobbing display certain diversity in terms of sub-themes.

Keywords: Mobbing, education instituions, psychological violence, victim of mobbing.

\section{GíRiş}

Etik, hukuk ve adli tıp açısından "psikolojik şiddet" diğer adıyla mobbing, latince "mobile vulgus" sözcüğünden gelmektedir (Eser, 2006; Tutar, 2004). Mobbing kavramının iş dünyası bağlamında, Leymann (1996) tarafından yapılan tanımı şöyledir: “Mobbing, duygusal bir saldırıdır. Bir veya birkaç kişi tarafından diğer bir kişiye yönelik olarak düşmanca ve ahlak dışı yöntemlerle sistematik bir biçimde uygulanan psikolojik bir terördür. Mobbing kavramı; işyerinde psikolojik terör, işyeri travması, işyerinde zorbalık, işyerinde psikolojik taciz, işyerinde duygusal saldırı, yıldırma, duygusal taciz (Çobanoglu, 2005:20) kavramlarına karşılık gelmektedir. Psikolojik şiddet, bireyin kişiliğine, itibarına, mesleki yaşamına, özel yaşamına doğrudan ya da dolaylı yoldan saldırıları ve cinsel tacizi de içermektedir. "Mobbing bir psikolojik şiddet veya psiko-terördür; ancak şiddetten söz edildiğinde, genelde fiziksel müdahale ve somut iz bırakan fiili şiddet akla gelmektedir. Oysa şiddet sadece kaba biçimi ile fiziksel olmayıp ekonomik, siyasal ve psikolojik olabilmektedir. Şiddetin inceltilmiş (rafine-sofistike) biçimi olan mobbing, fiziki şiddetten (bullying) daha tehlikeli ve daha kalıcı psikosomatik etkiler bırakabilmektedir (Tutar, 2004).

Mobbing, öncelikle iletişim unsurlarından uzak bırakılarak, sert eleştiri ve azarlama, yetenekleri görmemezlikten gelme, toplantılarda aşırı yüklenme, küçük düşürme, gibi öz saygıya yönelik saldırılar; daha sonra karalama, hakkında asılsız dedikodu çıkarma gibi sosyal statüye saldırı şeklinde kendini göstermektedir. İleri aşamalarında, şiddeti giderek artmakta, sözlü cinsel taciz (kadına), din, dil, ırk, fiziksel farklılık gibi konularda ayrımcılığa ve mağdurun işten ayrılması ve kovulmasına kadar ulaşabilmektedir. Psikolojik şiddet süreci, ya kişinin benliğini öldürüp koşulsuz itaatini sağlamakla veya istifasıyla sonuçlanmakta (Tutar, 2004) hatta intiharlarla son bulmaktadır.

Psikolojik terörün oluşumunda, uygulayanlar ve psikolojik özellikleri, şiddete maruz kalan mağdurun kişilik özellikleri ve içerisinde bulunduğu durum ile durumun oluştuğu örgüt kültürü ve iklimi rol oynayabilmektedir. Örgütsel yapının ve iklimin, mobbinge zemin hazırladığı bilinmektedir. Mobbingi, iki personel arasında süregelen çatışmadan ayıran özelliği, sistemli gelişen, uzun süreli olan ve sonuçları açısından bireyde psikolojik ve fizyolojik zararlara sebep olabilecek bir davranış ve çatışma türü olmasıdır (Browne ve Smith, 2008).

Mobbing, 1980'li yılların başlarından itibaren dünyada giderek genişleyen bir biçimde suç unsuru olarak tanımlanmakta ve yasalara geçirilmektedir. 1998 ILO (Uluslararası Çalışma Örgütü) Raporuna göre 1996 yılında Avrupa Birliği'nin 15 üye ülkesinde gerçekleştirilen 15800 görüşmenin sonuçları; bir önceki yıl içinde çalışanların, \%4'ünün (6 milyon çalışan) fiziksel şiddete, \%2'sinin (3 milyon çalışan) cinsel tacize ve $\% 8^{\prime}$ inin (12 milyon çalışan) mobbinge maruz kaldığını doğrulamıştır (Tınaz, 2006). Uluslararası arenada yapılan tüm araştırma sonuçlarının birleştiği ortak nokta, mobbing mağdurlarının, diğer şiddet ve taciz mağdurlarından çok daha fazla sayıda olduklarıdır (Tınaz, 2006). Son yıllarda giderek yaygınlaşan psikolojik şiddet-yıldırma uygulamalarına karşı batı toplumlarında gerek onları önlemeye yönelik gerekse mağdurların tedavisine yönelik çabalar oldukça yoğunlaşmıştır. Türkiye'de bu konuda yapılan çeşitli araştırmalar (Ocak, 2008; Otrar ve Özen, 2009; Tutar, 2004; Yılmaz, Özler ve Mercan, 2008; Koç ve Bulut, 2009), mobbingin, özellikle hizmet 
sektöründe ve kamu kurumlarında daha fazla rastlanan bir sorun olduğuna işaret etmektedir. Ancak hem kamu hem de özel kesimde faaliyet gösteren örgütlerde psikolojik şiddet-yıldırma uygulamaları sıkça görülmesine karşın iş yerlerinde yaşanan bu sürecin ne anlama geldiği henüz pek bilinmemektedir. Bu konudaki yasal düzenlemeler, Türkiye'nin imzaladığı Avrupa Sosyal Şartı'nın 26. Maddesindeki “Onurlu çalışma hakkının korunması ve sağlanması" boyutuyla sinırlı olup, henüz istenilen düzeyde gerçekleştirilememiştir.

Mobbing, hem çalışanlar hem de örgütler açısından birçok olumsuz sonuç yaratmaktadır. Mobbing, mutsuz bireylerin yer aldığ ve çalışma barışının bulunmadığı bir iş yaşamını ortaya çıkararak, büyük bir toplumsal problem haline dönüşmektedir. Mobbingin yaşandığ 1 örgütlerde; çalışanlarda işten ayrılma niyetinin oluştuğu, örgütsel bağlılıklarının azaldığı ve buna bağlı olarak işgören devir hızının arttığı bilinmektedir. Bu bağlamda bireysel ve örgütsel, hatta toplumsal düzeyde ciddi olumsuz sonuçlar doğurabilen mobbing olgusunun farkına varılması, nedenlerinin belirlenmesi ve önlemlerin geliştirilmesi büyük önem taşımaktadır. Eğitim kurumlarında da, örgütlerde, iş yaşamını zorlaştıran yeni bir kavram olan mobbingi araştıran çalışmaların (Cemaloğlu ve Kılınç, 2012; Tigrel ve Kokalan, 2009) sinırlı sayıda olduğu görülmüştür. Mobbing uygulamaları hakkında gerçekçi bir değerlendirme yapmaya ve önlenmesi için öneriler ortaya koymaya çalışan bu çalışmanın bu anlamda alandaki önemli bir eksikliği tamamlamada katkı sağlaması beklenmektedir. Aynı zamanda bu araştırma mobbingin, örgütsel etkililiğin ve verimliliğinin azalmasına ve çalışanlar üzerindeki zararlı etkilerine dikkat çekmesi ve eğitim kurumları tarafından dikkate alınmasının gerekliliğini ortaya koyması yönünden önem taşımaktadır. Bu bağlamda, bu araştırmanın amac1, eğitim kurumlarında karşılaşılan mobbing (yıldırma) uygulamalarının neler olduğunu ortaya koymak ve bulgular ışığında gelecekte yürütülecek çalışmalara yönelik öneriler geliştirmektir.

\section{Yöntem}

Araştırmanın bu bölümünde çalışma grubu, çalışmada kullanılan veri toplama aracı, verilerin toplanması ve analizine yer verilmektedir.

Nitel veri toplama teknikleri ile ele alınan bu araştırmada, yarı yapılandırılmış görüşme tekniği kullanılmıştır. Nitel araştırmalar, ürünlerden ya da çıktılardan daha çok süreç ile ilgilenmektedir. Dolayısıyla nitel araştırmalarda anlamlar önem taşımaktadır (Merriam, 1988: Akt. Yilmaz ve Altınkurt, 2011). Yarı yapılandırılmış görüşmeler ise sahip olduğu belli düzeydeki standartlığı ve esnekliğgi nedeniyle, yazmaya ve doldurmaya dayalı testler ve anketlerdeki sinırlılığı ortadan kaldırması ve belirli bir konuda derinlemesine bilgi edinmeye yardımc olması (Yildırım ve Şimşek, 2003) nedeniyle araştırmacılar tarafından sıklıkla tercih edilmektedir. Yarı yapılandırılmış görüşmeler ne tam yapılandırılmış görüşmeler kadar katı, ne de yapılandırılmamış görüşmeler kadar esnektir, iki uç arasında yer almaktadır. Araştırmacılara bu esnekliği sağladığı için yarı yapılandırılmış görüşme tekniği kullanılmıştır.

\section{Çalışma Grubu}

Araştırmanın çalışma grubunun belirlemesinde, amaçlı örnekleme yöntemlerinden ölçüt örnekleme yöntemi kullanılmıştır. Ölçüt örnekleme, örneklemin problemle ilgili olarak belirlenen niteliklere sahip kişiler, olaylar, nesneler ya da durumlardan oluşturulmasıdır (Büyüköztürk, Çakmak, Akgün, Karadeniz ve Demirel, 2009). Araştırmada, uygulamanın yapılacağı kurumların seçiminde araştırmacılar tarafından belirlenen temel ölçüt, gerçek mobbing mağduru olan katılımcıların bulunduğu kurumların seçilmesidir. Çünkü, bu araştırmada katılımciların mobbing sürecine ilişkin görüşleri ve gözlemleri belirlenmeye çalışılmıştır. Mobbing kavramı her kurumda yaşanan çatışmadan farklı bir kavramı belirtmektedir, bu nedenle durumun doğru betimlenebilmesi amaciyla mobbing sürecinden 
sağlık, maddi kayıplar ve işten ayrılma açısından olumsuz etkilenen katılımcılar çalışma grubuna dahil edilmiştir. Araştırma için ilk katılımcı basındaki bir haber aracılığıyla belirlenmiştir. Mobbing mağduru olan katılımcı ile yapılan ilk görüşmeden sonra, mağdur kendisi gibi hukuksal süreci başlatan bir başka katılımcıya araştırmacıları yönlendirmiştir.
Mobbing davalarında hukuksal süreç karmaşık olduğu için mağdurların birbirlerinin deneyimlerinden yararlanması araştırmacıların katılımcıları belirlemesinin yolunu açmıştır. Aynı zamanda "Mobbing ile Mücadele Derneği" aracılığıyla mobbing mağdurlarının birbirleri ile iletişim kurmaya çalıştıkları belirlenmiştir.

Tablo 1. Katılımcıların Demografik Özellikleri

\begin{tabular}{|c|c|c|c|c|c|}
\hline & M1 & M2 & M3 & M4 & M5 \\
\hline Cinsiyet & Kadın & Kadın & Kadın & Erkek & Erkek \\
\hline Yaş & 38 & 40 & 36 & 45 & 50 \\
\hline Mesleği & Öğretmen & Öğretmen & Öğretmen & Akademisyen & Akademisyen \\
\hline Görevi & Öğretmen & $\begin{array}{l}\text { Müdür } \\
\text { yardımcısı }\end{array}$ & $\begin{array}{l}\text { Müdür } \\
\text { yardımcısı }\end{array}$ & Doçent & Doçent \\
\hline Eğitim düzeyi & Lisans & Lisans & Lisans & Doktora & Doktora \\
\hline Kıdem Y1lı & $15 \mathrm{yil}$ & 18 yıl & 17 yıl & 15 yıl & 20 yil \\
\hline Medeni Durumu & Evli & Bekar & Evli & Evli & Bekar \\
\hline $\begin{array}{l}\text { Mobbinge Maruz } \\
\text { Kalma Süresi }\end{array}$ & $6 Y_{11}$ & 3 yil & 2,5 yil & 4 yıl & 2 y1l \\
\hline Mobbing sonucu & $\begin{array}{l}\text { Depresyon, } \\
\text { Maddi } \\
\text { Kayip }\end{array}$ & $\begin{array}{l}\text { Depresyon, } \\
\text { İşten Ayrılma }\end{array}$ & Depresyon & Depresyon & İstifa \\
\hline
\end{tabular}

Tablo 1 incelendiğinde araştırmaya katılan mobbing mağdurlarının 3'ünün evli, 5'inin lisans, 2'sinin doktora programı mezunu, tamamının mesleki kıdemlerinin 10 yılın üzerinde olduğu, branşlarının çeşitlilik gösterdiği (sınıf öğretmeni, felsefe, sosyoloji, yabancı dil ve bilgisayar eğitimi) görülürken, mobbing sürecinden tüm katılımciların olumsuz etkilendiği ve mobbing sürecinin en az 1 yıl sürdüğü, görülmektedir.

\section{Veri Toplama Aracı}

Araştırmada veri toplama aracı olarak yarı yapılandırılmış görüşme formu kullanılmıştır.
Karşılaştırmalı sonuçlar elde etmek amaciyla, tercih edilen yarı yapılandırılmış görüşme formu, araştırma soruları ve alan yazındaki bilgiler doğrultusunda mobbing mağdurları için geliştirilmiştir. Görüşme formunda, "mobbinge uğramanın nedenleri, mobbing uygulamaları, mobbingle baş etme yöntemleri ve mobbing uygulamalarının olumsuz etkileri" konularını ele alan sorular yer almaktadır. Araştırmacılar tarafından geliştirilen görüşme sorularının hazırlanmasında; soruların kolaylıkla anlaşılması ve çok boyutlu olmaması, yanıtlayıcıyı yönlendirici olmaması gibi ilkelere dikkat edilmiştir (Bogdan ve Biklen, 1992; Akt. 
Yılmaz ve Altınkurt, 2011). Hazırlanan görüşme formunun amaca ne derece hizmet ettiği, anlaşılırlığı ve uygulanabilirliğini kontrol etmek amacıyla alan uzmanlarının görüşlerine sunulmuştur. Uzmanların önerileri doğrultusunda görüşme formu düzenlenmiştir. İkinci aşamada bir mobbing mağduru ile ön uygulama yapılmış, herhangi bir sorun yaşanmadığı görülmüştür.

Araştırmada uzman incelemesi, katılımcı teyidi ve yöneticilerle yapılan görüşmelerin süreleri uzun tutularak da uzun süreli etkileşim yoluyla iç geçerlik (inandırıcılı̆̆ını) sağlanmaya çalışılmıştır. Ayrıca, verilerin inandırıcılığını artırmak için toplanan verilerden elde edilen bulguların tutarlılığı kontrol edilmiştir. Buna yönelik olarak bulguların, görüşme formunun geliştirilmesinde kullanılan kavramsal çerçeve ile uyumluluğu sürekli kontrol edilmiştir. Görüşmelerde en az iki araştırmacı görev alarak biri görüşmeyi yönetirken, diğeri süreci gözleyerek gerektiğinde ek sorular sormuş ve açıklamalar yapılmasını talep etmiştir. Böylece, olası veri kaybının önlenmesi ve verilerin araştırma sorularına uyumu sağlanmaya çalışılmıştır. Bunların yanı sıra görüşme yapılan mobbing mağdurlarından doğrudan alıntılar yapılarak da araştırmanın inandırıcılığı yükseltilmeye çalışılmıştır. Araştırmanın dış geçerliğini (aktarılabilirliğini) artırmak için araştırma süreci ve bu süreçte yapılan işlemler ayrıntılı bir şekilde betimlenmiştir. Bu bağlamda, araştırmanın modeli, çalışma grubu, veri toplama aracı, veri toplama süreci, verilerin çözümlenmesi ve yorumlanması, bulguların nasıl düzenlendiği ayrıntılı bir biçimde aktarılmıştır.

Araştırmanın iç güvenirliğini (tutarlığını) artırmak için bulguların tamamı yorum yapılmadan doğrudan verilmiştir. Ayrıca görüşmede elde edilen veriler üzerinde araştırmacılar ve nitel araştırma konusunda deneyimli bir öğretim üyesi ayrı ayrı kodlamalar yapmış ve kodlamalar karşılaştırılarak tutarlık oranı hesaplanmıştır. Araştırmanın dış güvenirliğini (teyit edilebilirliğini) artırmak için araştırmacıların konumları, çalışılan durumla ilgili ön deneyimleri, araştırmada veri kaynağ1 olan katılımcılar, araştırmanın yapıldığı sosyal ortam, elde edilen verilerin analizinde kullanılan kavramsal çerçeve, analiz yöntemleri ile ilgili ayrıntılı açıklamalara yer verilmiştir. Ayrıca, başka araştırmacıların talep etmesi ya da gelecekte başka bir araştırmada karşılaştırmalar yapmak amacı ile araştırmanın ham verileri saklanarak da dış güvenirlik artırılmaya çalışılmıştır.

\section{Verilerin Toplanması}

Araştırmanın verileri, katılımcıların kendilerini rahat ifade edebileceği ve ses kaydı yapılabilecek ortamlarda, kendilerinin randevu verdikleri zaman dilimlerinde toplanmıştır. Görüşme soruları her bir katılımcıya, aynı sözcüklerle ve aynı anlamı çağrıştıracak tonlamalarla yöneltilmiştir. Mobbing mağdurlarıyla yapılan görüşmelerde ses kayıt cihazı ve not alma tekniği birlikte kullanılmıştır. Daha sonra yapılan kayıtlar çözümlenmiştir. Görüşmelerin çözümlenmesinden 40 sayfa veri elde edilmiştir. Öncelikle, verilerin yazıya dökümü, dökümlerin doğruluğu sağlanmış, belirlenen temalara göre verilerin işlenmesi ve doğrudan alıntılarla bulguların yorumları yapılmıştır. Verilerin güvenirliğini sağlamak için kayıtlar ve kaydın dökümü araştırmacılar dışındaki başka bir araştırmacı tarafından incelenmiş ve araştırmacıların dökümleri ile karşılaştırılmıştır (Uzuner ve Çolak 2004: Akt. Yılmaz ve Altınkurt, 2011). Kayıtlar ile yazılı dökümler arasında çok küçük eksikliklerin olduğu belirlenmiş ve bu eksiklikler de giderilmiştir.

\section{Verilerin Analizi}


Araştırma verilerinin çözümlenmesinde betimsel analiz ve içerik analizi teknikleri kullanılmıştır. Betimsel analiz; elde edilen verilerin daha önceden belirlenen temalara göre özetlenip yorumlandığı, görüşülen bireylerin görüşlerinin çarpıcı bir biçimde yansıtmak amacıyla sık sık doğrudan alıntıların kullanıldığı ve elde edilen sonuçların nedensonuç ilişkileri çerçevesinde yorumlandığı analiz tekniğidir (Yıldırım ve Şimşek, 2003). Betimsel analiz tekniği üç etkinlik basamağı (verilerin azaltılması, verilerin sunumu, sonuç çıkarma ve doğrulama) çerçevesinde gerçekleştirilmiştir (Türnüklü, 2000). Verilerin sunumunda, alıntı seçimi için çarpıcılık (farklı görüş), açıklayıcılık (temaya uygunluk), çeşitlilik ve uç örnekler ölçütleri dikkate alınmıştır (Ünver, Bümen ve Başbay, 2010).

Formlardan elde edilen veriler öncelikle Office programına aktarılarak birkaç kez okunmuş ve buna yönelik kodlamalar oluşturulmuştur. Ardından kodlar bir araya getirilerek, araştırma bulgularının ana hatlarını oluşturacak temalar (kategoriler) ortaya çıkarılarak betimsel ve içerik analizleri yapılmıştır.

İçerik analizinde güvenirliğin belirlenmesi amacıyla genellikle kodlayıcılar arası tutarlılık hesaplanmaktadır. Görüşme dökümlerinin yazılması işlemleri tamamlandıktan sonra, görüşme soruları temel alınarak görüşme kodlama anahtarı hazırlanmıştır. Görüşme kodlama anahtarının güvenirliğini belirlemek amacıyla iki adet katılımcı görüşme dökümü formu yansız atama yoluyla seçilerek çoğaltılmış ve görüşme kodlama anahtarı ile birlikte araştırmacılar tarafından bağımsız olarak değerlendirilmiştir. Değerlendirme, görüşmecilerin görüşüne uygun bulunan seçeneğin ilgili görüşme kodlama anahtarına işaretlenmesi biçiminde yapılmıştır. Görüşme kodlama anahtarına işaretlemelerin tutarlılığını belirlemek amacıyla her sorunun yanitı tek tek incelenerek karşılaştırılmış ve bu aşamadan sonra görüşme kodlama anahtarlarına son biçimleri verilmiştir. Araştırmacılar, birbirlerinden bağımsız olarak her katılımcıya ait görüşme dökümü formunu okuyarak ilgili görüşme kodlama anahtarındaki her sorunun yanıtını içeren uygun seçeneği işaretlemişlerdir. $\mathrm{Bu}$ işlemden sonra araştırmacıların değerlendirmesi katılımcı gruba ait ilgili soruya verilen yanıt seçeneği kontrol edilerek, "Görüş Birliği" ve "Görüş Ayrılı̆̆ı" biçiminde işaretlemeler yapılmıştır. Araştırmacılar ilgili sorunun aynı yanıt seçeneğini işaretlemişlerse görüş birliği, farklı seçenekleri işaretlemişlerse görüş ayrılığı olarak kabul edilmiştir. Bu çalışmada içerik analizinde güvenirliğin belirlenmesi amacıyla uyuşum yüzdesi formülü kullanılmıştır. Uyuşum yüzdesi (Agreement percentage) "Güvenirlik = Görüş birliği / (Görüş Birliği + Görüş Ayrılı̆̆ 100" formülü kullanılarak hesaplanmıştır (Miles ve Huberman, 1994). Yıldırım ve Şimşek'e (2003) göre, güvenirlik hesaplamasındaki uyuşum yüzdesi \%70 olduğunda güvenirlik yüzdesine ulaşılmış kabul edilir. Çalışmada, bu formül kullanılarak kodlamalardaki uyuşum yüzdesi; birinci soru için 0.86, ikinci soru için 0.88 , üçüncü soru için 0.94 , dördüncü soru için 0.93 ve toplamda tüm sorular için genel uyuşum düzeyi ise 0.90 olarak hesaplanmıştır (Yıldırım ve Şimşek, 2003). Oranların \%70'in üzerinde olmasının araştırmacıların kodlama güvenirlikleri için yeterli olduğu düşünülmektedir. Verilerin analizi sonucunda ortaya çıkan tema ve alt temalar Tablo 2'de görülmektedir. 
Tablo 2. Verilerin Analizi Sonucu Ortaya Çıkan Tema ve Alt Temalar

1.Mobbingin nedenlerine ilişkin görüşler

1.1. Mağdura bağlı nedenlere ilişkin görüşler

1.2. Kuruma-ortama bağlı nedenlere ilişkin görüşler

1.3. Mobbingi uygulayana bağlı nedenlere ilişkin görüşler

2.Mobbing uygulamalarına ilişkin görüşler

2.1. İletişimi engellemeye ilişkin görüşler

2.2. Sosyal ilişkilere saldırıya ilişkin görüşler

2.3. İtibara saldırılara ilişkin görüşler

2.4. Mesleki duruma saldırılara ilişkin görüşler

2.5. Sağlığa yönelik saldırılara ilişkin görüşler

3.Mobbingle baş etme yöntemlerine ilişkin görüşler

3.1. Bireysel baş etme yöntemlerine ilişkin görüşler

3.2. Hukuksal mücadeleye ilişkin görüşler

3.3. Farkındalık geliştirmeye ilişkin görüşler

4. Mobbing uygulamalarının olumsuz etkilerine ilişkin görüşler

4.1. Bireysel olumsuz etkilerine ilişkin görüşler

4.2. Ailevi olumsuz etkilerine ilişkin görüşler

4.3. Örgütsel olumsuz etkilere ilişkin görüşler

Tablo 2.'de görüldüğü gibi araştırmada elde edilen verilere göre alt temaların oluşturulması sürecinde araştırmacılar ayrı ayrı tüm dökümleri okumuşlar ve yine birbirinden bağımsız olarak alt temaları oluşturmuşlardır. Daha sonra bir araya gelen araştırmacılar, verilerin dört alt tema altında toplanması konusunda uzlaşıya varmışlardır. Birinci ana tema olan "mobbingin nedenlerine ilişkin görüşler" başlığı altında mağdura bağlı nedenler, kuruma-ortama bağlı nedenler ve mobbingi uygulayana bağlı nedenlere ilişkin görüşler şeklinde alt temalar oluşturulmuştur. İkinci ana tema olan "mobbing uygulamalarına ilişkin görüşler" başlığı altında ise iletişim oluşumunu engellemek, sosyal ilişkilere saldırılar, itibara saldırılar, mesleki duruma saldırılar ve sağlığa yönelik saldırılara ilişkin beş alt tema oluşturulmuştur. Üçüncü ana tema olan "mobbingle baş etme yöntemlerine ilişkin görüşler" başlığı altında ise bireysel baş etme, hukuksal mücadele ve farkındalık geliştirmeye ilişkin görüşler şeklinde alt temalar ortaya çıkmıştır. Dördüncü ana tema olan "mobbing uygulamalarının olumsuz etkilerine ilişkin görüşler" başlığı altında ise bireysel, ailevi ve örgütsel olumsuz etkilere ilişkin görüşler yer almaktadir. 


\section{Bulgular}

Katılımcıların görüşleri, gizlilik esasına dayanılarak, isimleri verilmeden kodlanarak aktarılmıştır. Buna göre mobbing mağduru katılımcılar için "mobbing mağduru"nu ifade etmesi açısından " $\mathrm{M}$ ” olarak kodlanmış ve her katılımciya kodunun yanında “M1, M2, M3, M4, ve M5" şeklinde bir numara verilmiştir. Araştırmanın bu bölümünde, görüşme formunda yer alan sorular alt problemlere göre gruplanmış ve bulgular sunulmuştur.

\section{Mobbingin Nedenlerine İlișkin Görüssler}

$\mathrm{Bu}$ alt problem doğrultusunda görüşme formundaki soru, "Mobbinge uğramanızın nedenleri nelerdir?" şeklindedir. Bu alt problem doğrultusunda alınan yanıtların analizi sonucunda üç alt tema ortaya çıkmıştır: mobbingi uygulayana bağlı nedenler, kuruma-ortama bağlı nedenler ve mağdura bağlı nedenler. Bu üç alt temayı oluşturan kavramlar incelendiğinde mobbing mağdurları tarafindan en fazla vurgulanan noktanın, kurum kültürünün olumsuz olması (M1, M2, M3, M4 ve M5) ve ikinci olarak mobbing mağdurunun alandaki yeterliliğininbaşarısının yüksek olması, olduğu görülmüştür (M1, M3, M4 ve M5).

\section{a) Mă̆dura bağlı nedenler}

Katılımcılar kendilerine ilişkin olarak kariyerde yükselme, düzene karşı koyma, entelektüel birikim, değer anlayışı, alanda yeterlilik-başarı, gelişime açık olma, işini sevme, mobbing hakkında bilgisizlik ve sosyal kişilik konularında benzer görüş belirtmişlerdir. Bu alt temaya göre mobbing mağdurları tarafından vurgulanan bazı görüşler ise şöyledir;

Katılımcılardan biri, alanda yeterlilik-başarı konusunda "Uzun bir süre dershanede çalışmış olmam nedeniyle sınflarımın başarı yüzdeleri hep yüksek olurdu, onunkileri ise hep düşük olurdu." (M1) şeklinde görüşünü belirtirken diğer bir katılımc1 "Düzenlemiş olduğumuz kurultaydaki başarı, bölüm içindeki aktivitelerimiz ve profesörlük kadrosu için yeterliliği zaman kaybetmeden să̆lamış olmam üst yöneticiyi ürküttü. Kadro alırsam onun yerine gelmek isteyeceğimi düşündü. Halbuki benim böyle bir düşüncem yoktu." (M4) şeklinde görüşünü belirtmiştir. Bir başka katılımcı ise "Bölümde, yabancı dili olan tek bendim, yayın dosyam onlara göre daha güçlüydü." (M5) diyerek diğer iki katılımcının görüşünü desteklemiştir. Katılımcılara göre mobbinge uğrama nedenlerinden biri de mağdurun karakteristik özellikleridir (M2, M3, M4 ve M5). Bazı katılımcıların görüşleri şöyledir: "Nasıl çalıştı̆̆ımı bilir. Yapımı bilir, otoriteye karşı çıkmam, sadece işimi yaparım, ama otoriye ă̆am paşam demediğimi de bilir. Doğru bildiğim neyse söylerim." (M2) ve "Doğru bildiklerimi yaparım. Yönetim, görevlerimi yapmamamı istedi, ancak bu tür uygunsuz müdahalelere asla taviz vermem." (M4). Katılımcılara göre mobbinge uğramanın bir başka nedeni sosyal kişiliğe sahip olmaktır (M1, M2 ve M5). Buna göre bir katılımcının görüşü: "Ben faal bir öğretmenim, idareci olurum, diye endişeleniyordu. ...Örneğin, ögrrenciler kendilerine yakın hissettikleri için sosyal etkinlikleri organize etmemi istiyorlardı. Öğrencilerim istediği için, "Martı Şenliği"ni düzenledik." (M1). Başka bir katılımcı mobbing konusundaki bilgisizliğini (M1) ise "Psikolojim bozulmaya başlayıp yardım almaya başlayana kadar, bunları sadece benim yaşadığımı zannediyordum. Mobbing konusunda cahil olduğumu düşünüyorum. O kadar şahidim varken "bu işin peşine düşmediğim için çok pişmanım. Bu kadar uzun sürmezdi." şeklinde vurgulamıştır.

\section{b) Kuruma-ortama bă̆lı nedenler}

Katılımcılar kuruma-ortama ilişkin olarak maddi kazanç sağlama, yönetim tarzı-zayıf liderlik, olumsuz kurum kültürü konularında benzer görüş belirtmişlerdir. $\mathrm{Bu}$ alt temaya göre mobbing mağdurları tarafından vurgulanan bazı görüşler ise şöyledir; 
Maddi kazanç sağlama konusunda üç katılımcının (M1, M3 ve M5) benzer görüşleri olduğu görülmüsşür. Bir katılımcı "Beni rahatsız eden "para kazanma çetesi" olarak adlandırdı̆̆ım oluşum. Onlara karşıysanız bir şekilde bu onların aklında yer ediyor. Görev almada, haftalik ders programında bile ikinci plana itiliyorsunuz." (M5) şeklinde görüşünü belirtirken, diğer bir katılımc1 ise "Sosyoloji öğretmeni olmama rağmen anasınıfı öğretmeni olarak görevlendirildim. Mali işlerin sorumluluğu bana verildi. Bu görevlendirmenin asıl amactnın, velilerden toplanan paralarm müdüre elden teslim edilmesini ve okul hesabına yatırılmamasını sağlamak, olduğunu anladım. Müdürün dahil olduğu bir grup, bu paraları kullanmak istiyordu. Ben de red ettim. Imalı konuşmalar, tekme ile sınıfa gelmeler, okuldaki öğretmenler tarafindan dışlanma, tehditler, ölüm tehdidi ol$d u . . . . . "$ (M3) şeklinde görüşünü desteklemiştir. Tüm katılımcılar (M1, M2, M3, M4 ve M5) mobbing nedenleri arasında kurum kültürü kavramını vurgulamışlardır. Bu konudaki bazı görüşler şöyledir: "Herkes, bana dokunmayan yılan bin yıl yaşasın, diyordu. Müdür yardımcısının yaptıkların görmezden geliyorlar, hatta meşru olarak görüyorlardı." (M1); "Okula başlamadan önce, okul hakkında bilgi almak için, telefon ettim. Idarecilerden biri "Buranın birçok sorunu var, sen bu sorunlarn üstüne geldin" dedi. Görüşmeye gittiğimde ise "Siz buraya gelmeseydiniz başkaları gelecekti." dedi. Okulda matematik öğretmenine ihtiyaç olduğunu, felsefe öğretmenine ihtiyaç olmadığını söyledi. Onlara göre felsefe gereksiz bir dersti. Ben okula gelmeden dedikodum yapılmış 'matematik görünümlü felsefe öğretmeni gelecek' demişler." (M3) ve "Üst yönetimle arası iyi olanlar ya da bunu gelecekte bir firsat olarak değerlendirmek isteyenler, zamanla üst yönetime daha çok yaklaşıp benden uzaklaştılar. Üst yönetime iyi görünmek ve bireysel olarak yararlanmak isteyenler mobbing konusunda yönetime yardımcı oldular." (M4). Katılımcılardan bazıları (M1 ve M4) yönetim tarzı-zayıf liderlik açısından mobbinge maruz kaldıklarını belirtmişlerdir. Bir katılımcının görüşü şöyledir: "Kalite yöneticinin umurunda değil, yeter ki koltuğuna zarar gelmesin. Eski yöneticiler yerlerine kirli kararlar ve uygulamaları gizleyebilecek yönetimlerin gelmesini sağlıyorlar. Kendi adamlarından oluşan bir kadro oluşturup, düzeni devam ettiriyor." (M4).

\section{c) Mobbingi uygulayana bağlı nedenler}

Katılımcılar, mobbingi uygulayanın psikolojik durumu, güç bağımlılığı, kişiliği, otoriter olması, kıskançlı̆̆ı, rekabet anlayışı, hırslı olması, önyargılı olması, çatışmadan hoşlanması, alanda yetersiz olması, saygınlığını yükseltme ihtiyacı hissetmesi konularında benzer görüş belirtmişlerdir. Bu alt temaya göre katılımcılar tarafından vurgulanan bazı görüşler ise şöyledir;

Mobbing yapanın psikolojik durumu konusunda iki katılımcının (M1 ve M2) benzer görüşleri olduğu görülmüştür. Bir katılımcı "Estetik kaygıları olan biriydi, rahatsızlıklarını sık sık ifade ederdi. Kendisi ile barışık olmadığını düşünüyorum. Çok zayıf, orta boylu, sürekli mavi lens takan..., kompleksli biri. Gerçek göz rengini hiç görmedim." (M1) şeklinde psikolojik durumu vurgulamıştır. Katılımcılardan bazıları (M3, M4 ve M5) önyarg1 nedeniyle mobbinge maruz kaldıklarını belirtmişlerdir. $\mathrm{Bu}$ konuda bir katılımcının görüşü (M3) şöyledir: "Kayıp bir evrak vardı. Müdür önyargılıydı. Suçlandım. Kendimi savunmaya çalıştım, ama işe yaramadı... Beni dinlemek istemedi." Mobbinge uğrama nedeni olarak rekabet anlayışı konusunda, iki katılımcının görüşü (M1 ve M2) benzer doğrultuda bulunmuştur. $\mathrm{Bu}$ görüşlerden biri şöyledir: “A... okul müdürlüğ̈̈nü uzun süre vekaleten yürüttü. Beni rakip olarak görüyordu, amacı beni ortamdan uzaklaştırmaktı. Bir arkadaşıma "Sınavdan, benden daha yüksek puan alırsa kahrolurum" demiş. Kendisinden beş puan yüksek aldım. Onun çalışma yılı benden fazla olduğu için A... okulumuza atandı. Sınav döneminde bazı arkadaşlarımızı 
arayarak "sakın bu okulu yazmayın, eğer bu okula gelirseniz burada çalıştığınıza pişman ederim" demiş." (M2). Buna ek olarak mobbinge uğrama nedeni olarak iki katılımcı (M3 ve M4) alanda yetersizlik konusunda benzer görüş belirtmişlerdir.

\section{Mobbing Uygulamalarının Türlerine İlişkin Görüşler}

$\mathrm{Bu}$ alt problem doğrultusunda görüşme formundaki soru, "Mobbing sürecinde neler yaşadınız?" şeklindedir. Bu alt problem doğrultusunda alınan yanıtların analizi sonucunda beş alt tema ortaya çıkmıştır: iletişimi engelleme, sosyal ilişkilere saldırı, itibara saldırı, kişinin yaşam kalitesi ve mesleki durumuna saldırı ve kişinin sağlığına saldırı. Bu beş alt temayı oluşturan kavramlar incelendiğinde mobbing mağdurları tarafindan en fazla vurgulanan noktanın, söylenti (M1, M3, M4 ve M5) ve mobbing mağdurunun dışlanması, olduğu görülmüştür (M2, M3, M4 ve M5).

\section{a) İletişimi engellemek:}

Katılımcılar iletişimi engellemek açısından bağırma, eleştiri, ima, azarlama, hakaret ve kısıtlama konularında benzer görüş belirtmişlerdir. $\mathrm{Bu}$ alt temaya göre mobbing mağdurları tarafından vurgulanan bazı görüşler ise şöyledir;

Katılımcılardan biri iletişimi engellemek açsından kısıtlayıcı davranışların kullanılmasını "Dekan bölüm toplantısı yapmamı istemiyordu. Bölümdeki hizmetli bile dekana habercilik yapıyordu. Hizmetli, toplantıya başladığımda yönetimi arıyordu. Dekan gelip, toplantıyı kesiyordu." (M4) şeklinde belirtmiştir. Bir başka katılımcı iletişimi engellemek açısından azarlamanın kullanıldığını belirtmiş̧tir. Bu konuda görüşü şöyledir: “Çok sinirliydi. Okulun kurallarının değişeceğini bilmek onu gerginleştirmişti. Kendisine engel olamıyordu. Sinıfa sira istediğim için beni azarlamaya başladı. Daha sonra hiçbirini hatırlamadığını gördüm." (M3).

\section{b) Sosyal ilişkilere saldırı:}

Katılımcılar sosyal ilişkilere saldırı olarak mobberlerin gruplaşması ile sosyal iletişimin engellemesi, dışlama, arkadaşlarına zarar verme ve yok sayma davranışları konularında benzer görüş belirtmişlerdir. Bu alt temaya göre mobbing mağdurları tarafından vurgulanan bazı görüşler ise şöyledir;

Sosyal ilişkilere saldırı açısından katılımcılardan bazıları (M2, M3, M4 ve M5) dışlamanın kullanıldığını belirtmişlerdir. Bir katılımonın görüusü şöyledir: "Okula başladığımda, ü̧̈ ay boyunca rehberlik odasinda memur gibi oturmak zorunda kaldım. Diğger öğretmenlerle tanıştırılmadim, beni memur zannetmişler, dişlandim. Kendimi çok değersiz hissediyordum, bana hiçbir iş verilmiyor, hiç kimse benimle konuşmuyordu." (M3).

\section{c) İtibara saldırılar:}

Katılımcılar itibara saldırı olarak taklit, itibarını düşürme, kararını yok sayma, söylenti, karalama, davranışın kontrol edilmesi, itimatsızlık, akıl hastası gibi davranma, açık arama ve dalga geçme davranışları konularında benzer görüş belirtmişlerdir. Bu alt temaya göre mobbing mağdurları tarafından vurgulanan bazı görüşler ise şöyledir;

İtibara saldırılar açısından katılımcılardan bazıları (M1, M3, M4 ve M5) söylenti konusunda benzer görüş belirtmişlerdir. Bir katılımcıların görüşü şöyledir: "Karalama kampanyası düzenlendi. Hatalı bir uygulamanın düzeltilmesi konusunda bir dilekçe yazdım. Yazdığım dilekçe konusunda asılsız bir söylenti yayıldı. Siyasal bir eylem gerçekleştirdiğim iddia edildi. Bana "Sen bildiri yazmışsın, dağıtıyormuşsun, insanları ayartmaya çalışııorsun" dendi. Arkasindan görevden alındım. Geçici görevlendirme ile başka bir fakülteye gönderildim." (M5). Akıl hastası gibi davranma konusunda bir başka görüş şöyledir: "Müdürle dokuz yıldır birlikte çalışıyorduk. Daha önce, her yerde benim çalı̧malarımı överken, şimdi 
onları kandırmak ve hiç çalışmamakla suçluyordu. "Ben, sana göstereceğim, sana soracă̆ım. Sen hastasın, hasta ruhlusun, bir avuç ilaç kullanıyorsun,... diyordu." (M2) şeklinde görüşünü belirtmiştir.

\section{d) Mesleki duruma saldirilar:}

Katılımcılar mesleki duruma saldırılar açısından görev yerini değiştirme, üst birimlere-yasal prosedürlere ulaşmayı engelleme-özgüveni etkileyecek işler verme, görevinden alınma, görev vermeme, eşyaya zarar ve çalışmaların engellenmesi konusunda benzer görüş belirtmişlerdir. $\mathrm{Bu}$ alt temaya göre mobbing mağdurları tarafından vurgulanan bazı görüşler ise şöyledir;

Görev vermeme konusunda, katılımcilardan bazıları (M3, M4 ve M5) benzer görüş belirtmişlerdir. Bir katılımcının görüşü şöyledir: "Görev dağılımında önemli işler diğer müdür yardımoısına verildi. Bana sekreterya işleri, tahakkuk işleri verildi." (M3). Görevden alınma konusunda ise üç katılımcının (M4, M3, M5) görüşleri benzerdir. Bir katılımc1 (M4) "Benim atanmam gereken kadroya kısa bir süre sonra biri atandı. Hatta üniversite dışından, alanla ilgili olmayan birilerine kadro için teklifte bulunulduğunu öğrendim." Ekonomik zarar konusunda ise, bir katılımcı "Benim yokluğumda odama birkaç kez girilip ortalı̆̆ın dă̆ıtıldı̆̆ııı gördüm." (M4) şeklinde görüş belirtirken aynı katılımcı yasal prosedürlere ulaşmayı engelleme konusunda "Dört yıldır rektörden bir randevu bile alamadım, bölüme kadro talebi dilekçesi verdim. Bölüm kurulu, dilekçemi bir üst yönetime iletmedi. Altı ay bekledim, altı ay sonra bir dilekçe daha verdim. Gelen yanıt aynıydı." (M4) şeklinde başka bir görüş belirtmiştir.

\section{e) Să̆lı̆̆a saldırılar:}

Katılımcılar sağlığa saldırılar olarak iş yükünü arttırma, fiziksel şiddet ve tehdit konusunda benzer görüş belirtmişlerdir. $\mathrm{Bu}$ alt temaya göre mobbing mağdurları tarafından vurgulanan bazı görüşler ise şöyledir;

Katılımcılardan bazıları (M1 ve M2) fiziksel şiddetin kullanıldığını belirtmiştir. Bu konuda bir katılımcının görüşü şöyledir: "Müdür yardımoss beni birçok şeyle itham etti,... "Seni bu okulda istemiyorum, istifanı yaz, burada seni çalıştırmam, seni huzursuz edeceğim," tehditlerini savuruyordu... Okul müdürü üstüme yürüdü. Herkes toplandı. Bana atılmaya çalışan tokadı, araya giren bir bayan arkadaş yedi." (M2). İş yükünü artırma konusunda bir katılımcının görüşü ise şöyledir: "...Tez danışmalı̆̆ım çoktu, ders saatim 20'yi geçiyordu. Bu amaçla dilekçe vermiştim. Uygun bulunursa, lisans dersi almak istemediğimi belirttim... Dilekçem hem dikkate alınmad, hem de istemediğim bölümlerde derslerime ek olarak 16-18 saat ders yüklendi." (M5)

\section{Mobbingle Baş Etme Yöntemlerine İlişkin Görüşler}

$\mathrm{Bu}$ alt problem doğrultusunda görüşme formundaki soru, "Mobbingle baş etmek için neler yaptınız?" şeklindedir. Bu alt problem doğrultusunda alınan yanıtların analizi sonucunda üç alt tema ortaya çıkmıştır: bireysel baş etme yöntemleri, hukuksal mücadele ve farkındalık geliştirme yöntemleri. Bu üç alt temayı oluşturan kavramlar incelendiğinde mobbing mağdurları tarafindan en fazla vurgulanan noktanın, kaçınma (M1, M2, M3, M4 ve M5) ve paylaşma- sosyal etkileşim yöntemi (M1, M2, M3 ve M4) olduğu görülmüştür.

\section{a) Bireysel baş etme yöntemleri:}

Katılımcılar bireysel baş etme yöntemleri açısından paylaşma-sosyal etkileşim, savunma, kaçınma, psikolojik destek alma, itaat, gizleme, yok sayma, gruptan yardım talebi, kişisel gelişim, karşı çıkma, eylemsizlik, önemsememe ve iletişim, vb. konularında benzer görüş belirtmişlerdir. Bu alt temaya göre mobbing mağdurları tarafından vurgulanan bazı görüşler ise şöyledir; 
Kaçınma davranışının kullanılması konusunda, tüm katılımcılar benzer görüş belirtmişlerdir. Bazı katılımcıların görüşleri şöyledir: “Öğretmen arkadaşlarımı evime davet ettim. Kendisini davet etmedim. Çünkü özel hayatımda onu yaşamak istemedim...... Ondan kaçmak için uzun süre rapor kullandım, okula gitmek istemedim." (M1), "Bu ortamda birikimimi yeterince değerlendiremeyeceğime karar verdim. Bu yüzden emekli oldum." (M5) ve "Normalde çok aktiftim. Bu süreçte hiçbir şeye bulaşmadım. Okulda genelde okul müdürünü görmemeye çalışıyordum. Görev saatinde geliyor, odamdan çıkmıyordum." (M2). Katılımcılardan bazıları ise paylaşma-sosyal etkileşim (M1, M2, M3 ve M4) ve psikolojik destek (M1 ve M3) yöntemlerini kullandıklarını belirtmişlerdir. Bazı katılımcıların görüşleri şöyledir: "Eşim çok destek oldu, motive etti. Hem maddi hem manevi yönden yanımdaydı... yaşadıklarımı arkadaşımla paylaşıyordum." (M3). "Bu süreçte, çok üzüldüm. Psikolojik yardım almak zorunda kaldım. Antidepresan kullandım." (M1) şeklinde belirtmiştir. İki katılımcı (M1 ve M3) ise yaşadıkları duru$\mathrm{mu}$ gizlemeye çalıştıklarını belirtmişlerdir. Katılımcılardan bazıları kişisel gelişim yöntemini kullandıklarını belirtmişlerdir. Bu konuda bir katılımcının görüşü şöyledir: "Yüksek lisans yapmak istiyordum. Sürekli bir şeyler okuyor, öğrenmeye çalışıyordum... Kişisel gelişim kitapları okuyordum. Nerde yanlıs yapıyorum, kendimde neleri değiştirebilirim diye düşünüyordum." (M3). Katılımcilardan bazıları (M2 ve M3) gruptan yardım alma konusunda görüş belirtmişlerdir.

\section{b) Hukuksal mücadele}

Katılımcılar mobingle baş etme yöntemleri açısından dava etme, üst yönetime başvurma ve veri toplama konularında benzer görüş belirtmişlerdir. Bu alt temaya göre mobbing mağdurları tarafından vurgulanan bazı görüşler ise şöyledir;

Katılımcilardan bazıları (M1 ve M4) dava etme yönteminin kullanılması konusunda benzer görüş belirtmişlerdir. Bazı katılımcıların görüşleri şöyledir: "İdari mahkemeye başvurdum. Haklı bulundum. Okula bir ceza geldi. Karar durduruldu." (M1) ve "Akademik yapilanmanin, en üst yönetim birimlerine, çeşitli üniversitelerin rektörlüklerine, siyasi ve idari en üst makamlara, parlementoya gittim, hiçbirinden bir sonuç alamadım." (M4). Hukuksal mücadeleyi başlatmak için veri toplama konusunda bir katılımcı görüşü şöyledir: "Elimde deliller olsun diye, tarih tarih söylediklerini kaydediyordum... Okuldan gidemezsem yasal yollara başvuracaktım ya da istifa edecektim, fakat müdür oldum." (M2). Katılımcılardan bazılar1 (M1, M2, M3 ve M4) üst yönetime başvurma yöntemini kullandıklarını belirtmişlerdir. $\mathrm{Bu}$ konuda bir görüş şöyledir: "İlçe milli eğitim müdürüne durumu anlattım. Bir çözüm bulmadı. Daha çok arkamda durmasını beklerdim. "Sinavlar olacak onlara gir", sonra bir çözüm buluruz, dedi." (M2).

\section{c) Farkındalık geliştirme:}

Mobbingle baş etme yöntemleri açısından katılımcılardan bazıları (M2 ve M3) farkındalık geliştirme yönteminin kullanılması konusunda benzer görüş belirtmişlerdir.

\section{Mobbing Uygulamalarının Olumsuz Etkileri- ne İlişkin Görüşler}

$\mathrm{Bu}$ alt problem doğrultusunda görüşme formundaki soru, "Mobbing uygulamalarının olumsuz etkileri nelerdir?" şeklindedir. Bu alt problem doğrultusunda alınan yanıtların analizi sonucunda dört alt tema ortaya çımıştır: bireysel etki, ailevi etki, örgütsel etki ve toplumsal etki. Bu üç alt temayı oluşturan kavramlar incelendiğinde mobbing mağdurları tarafından en fazla vurgulanan noktaların, kapasite altı çalıştırılma (M1, M2, M3, M4 ve M5), ailenin huzurunun bozulması (M1, M2, M3 ve M4) ve psikolojik etki (M1, M2, M3 ve M4) olduğu görülmüştür 


\section{a) Bireysel olumsuz etki}

Katılımcilar mobbing uygulamalarının olumsuz etkileri açısından bireysel etkiler olarak fiziksel zarar, psikolojik etki, stres, arkadaşlıkların kaybı, kaza masrafları, ilaç giderleri ve kapasite altı çalıştırılma konularında benzer görüş belirtmişlerdir. Bu alt temaya göre mobbing mağdurları tarafından vurgulanan bazı görüşler ise şöyledir;

Bireysel olumsuz etkiler açısından tüm katılımcılar kapasite altı çalıştırılma konusunda benzer görüş belirtmişlerdir. Bir katılımcıların görüşü şöyledir: "Okula çok isteksiz gidiyordum. Hiç bir şey yapmak istemiyordum. Önceden pazartesi sendromu nedir bilmezdim. Her günüm sendrom oldu. Okuldan kaçmak için her yola başvurdum, çalışkanlı̆̆ın devlet okulunda beş para etmediğini öğrendim." (M2) ve "Alandaki birikimimi kullanamadım. Çalışmalarımı engellediler, kitap projem vardı, onu engellediler, rektör müdahale etti. Derse giriyorum aklım sorunlarda, kafam hep dă̆g$n \imath k, . . . "$ (M4). Fiziksel zarar konusunda katılımcılardan bazıları (M1, M2 ve M3) görüş belirtmişlerdir. Bir katılımcının görüşü şöyledir: "Israrına dayanamayıp sigara içmeye başladım. Eşi tarafindan taciz edildim. Eşi ile tokalaşırken, elimi o kadar sıktı ki elimdeki yüzükler parmaklarıma battı ve parmaklarm kanadi." (M1). Psikolojik olumsuz etkiler konusunda ise dört katılımcı (M1, M2, M3 ve M4) benzer görüş belirtmiştir. Bir katılımcının görüşü şöyledir: "Yüzümün ifadesi kötü, rengim kaçıktı. Kendimi mutsuz, umutsuz ve çok değersiz hissediyordum. Sürekli stresliyim. Kişisel bakımımı, bir dönem aksattım, makyaj yapmak istemiyordum, giyinmek istemiyordum." (M3). Bir başka katılımcının, maddi kayıp konusundaki görüşü ise "Arabama, molotof kokteyli attırdl. Polis geldi, tutanak tutuldu. Arabam yandr." (M1) şeklindedir.

\section{b) Ailevi olumsuz etki}

Katılımclar mobbing uygulamalarının olumsuz etkileri açısından ailevi etkiler olarak çocukla- ra etki, aile ile çatışma ve ailenin huzuru (M1, M2, M3 ve M4) konularında benzer görüş belirtmişlerdir.

\section{c) Örgütsel olumsuz etki}

Katılımcilar mobbing uygulamalarının olumsuz etkileri açısından örgütsel etkiler olarak izin alımı, düşük iş kalitesi, yasal işlem/dava masrafları, erken emeklilik, kurumsal saygınlığın düşmesi, hastalıklı kurum, kısıtlanmış yaratıcılık konularında benzer görüş belirtmişlerdir. $\mathrm{Bu}$ alt temaya göre mobbing mağdurları tarafından vurgulanan bazı görüşler ise şöyledir;

M1, M2 ve M3 kodlu katılımcilar kurumsal saygınlığın düşmesi konusunda benzer görüş belirtmişlerdir. Bir katılımcının görüşü şöyledir: "Müdür bey bir öğretmeni bağırıp çağırarak azarlamıştı. Öğretmen sendikalı olduğu için sendika yetkilileri görüşmeye gelince müdür bey geri çekildi." (M2). Başka bir katılımcı ise "İlçe milli eğ itim, okulla ilgili şikayetler ulaşınca sorunlar olduğunu anladı. Müdür yardımcısına (müdür yetkili) görevinden ayrulması gerektiği söylendi.., okulun öğrencisi azaldı,.... Okulun kurumsal imajı zedelenmişti." (M3). Katılımcılardan bazıları ise (M1, M2 ve M4) hastalıklı kurum konusunda benzer görüş belirtmişlerdir. Bu konuda bir katılımc1nın görüşü şöyledir: "Kurumda birçok kişi olumsuz etkilendi. Organizasyon yaptığımızda, bize engel olurdu. Okulda iki grup öğretmen oluştu, korkusundan yanında olanlar ve uzak duranlar. Öğretmenleri evime davet ettiğimde 5-6 kişi korkusundan gelemedi." (M1).Personel hareketi sıklaştığı için uzmanlık kaybı konusunda ise bazı katılımcılar (M2, M4 ve M5) benzer görüşler sunmuşlardır.

\section{Tartışma}

Mobbing mağdurlarının, mobbinge maruz kalmalarının nedenlerine ilişkin verdiği yanıtlar mobbing mağdurlarının kendisine, kurumortam ve uygulayana bağlı nedenler şeklinde gruplandığını göstermiştir. Koç ve Bulut'a 
(2009) göre, MEB'e bağlı özel öğretim kurumlarında çalışan öğretmenler daha fazla mobbinge maruz kalmaktadır. Mercan'a (2007) göre öğretmenlerin kendilerini yenileyememeleri nedeniyle mobbinge maruz kalmaktadırlar. Araştırmalara göre üstlerin astlarına uyguladıkları mobbing oranı, aynı seviyedeki çalışma arkadaşından veya astından daha yüksektir (Einarsen, 1999; Kök, 2006; O'Moore ve arkadaşları, 2003). Bunun yanında Çobanoğlu'a (2005) göre mobbing mağdurları, duygusal zeka açısından oldukça gelişmiş insanlardır. Mağdurların yüksek korku ve endişe düzeyleri, hakkını aramaktan ve kendini savunmaktan çekinen ve çatışmadan kaçan, dürüst ve iyi niyetli kişiler olduğunu göstermektedir (Aquino ve Byron, 2002). Yücetürk (2003) ise mağdurların; zeki, yetenekli, yaratıcı, başarı yönelimli, dürüst, güvenilir ve politik davranmayan kişiler olduğunu işaret etmektedir. Bir başka araştırma, mağdurların işini çok iyi yapan, çalışma ilkeleri ve değerleri sağlam ve bunlardan ödün vermeyen, dürüst, güvenilir ve işleriyle özdeşleşen (Zapf, 1999) kişiler olduğunu göstermektedir. Öte yandan araştırmalara göre, mobbing davranışı sergileyen kişiler kendine güveni olmayan, kıskanç, kuşkucu ve, kendi eksikliklerinin telafisi için yıldırmaya başvuran güçsüz ve korkak insanlardır (Öztürk ve arkadaşları, 2007; Leymann, 1996). Yılmaz, Özler ve Mercan'ın (2008) araştırmasına göre mobbingin nedenlerinden biri kötü örgüt iklimidir. Agervold'a (2007) göre eğitim düzeyine rağmen zayıf sosyal iklime sahip ve saldırgan kültürlerde çok önemli oranlarda iş yeri taciz davranışı sergilenebilmektedir. Bazı araştırmalara göre mobbingin, sosyo-kültürel etkenlere bağlı olduğu bulunmuştur (Timmerman ve Bajeme, 2000; Kök, 2006). Zapf (1999) ise mobbinge neden olarak örgütü, sosyal grupları ve mağdurun sahip olduğu özellikleri belirlemiştir. $\mathrm{Bu}$ çalışma ve alanyazın doğrultusunda elde edilen bulgular, mobbingi ortaya çıkaran nedenle- rin, yöneticiler tarafından etkili bir şekilde çözümlenemediğini göstermektedir. Bu sonuç, yöneticilerin etkili liderler olamaması ve bireylerde etik kültürün oluşturulamamasından kaynaklanabilir.

Mobbing mağdurlarının, mobbing uygulamalarının türlerine ilişkin verdiği yanıtlar iletişimin engellemesi ile sosyal ilişkilere, itibara, mesleki duruma ve sağlığa saldırı şeklindedir. Bu konuda Yıldırım ve Yıldırım'a (2006) göre, en çok görülen mobbing davranışları başkasını küçümseme, suçlama ve sürekli kontrol etme davranışlarıdır. Akı'ya (2006) göre, Türkiye'de sindirme, yıldırma, yalıtma ve aşağılama yoluyla kişiyi işten çıkarmaya zorlama bir yönetim biçimi olarak benimsenmektedir. Bazı araştırmalara göre, mobbing daha çok öğretmenlerin yaşam kalitesini düşürmeye yöneliktir (Koç ve Bulut, 2009; Çalışkan, 2005; Tarhan, 2004). Cemaloğlu ve Ertürk'ün (2008) araştırmasına göre ise kendini gösterme ve iletişim, sosyal ilişkiler, itibara saldırı, yaşam kalitesi ve mesleki durum boyutlarında, yıldırma eylemi görülmektedir. Yukarıda ele alınan alanyazından ve bu araştırma sonucundan elde edilen bulgulara göre, mobbingte amaç, mağdurun itaat etmesinin sağlanmasıdır. Bu nedenle mobbing uygulayıcıları, amaca ulaşmak için birçok yöntemi birarada kullanmaktadırlar. Mobbingin uyguland1ğ1 kurumlarda birçok yöntemin rahatlıkla kullanılabilmesi, şeffaf yönetim ve etkili denetim yapılarının kurulamadığının ve mobbing konusunda farkındalık geliştirilemediğinin göstergesi olabilir.

Mobbing mağdurları, mobbing uygulamalarıyla baş etmede, bireysel baş etme, hukuksal mücadele ve farkındalık geliştirmeyi kullanmaktadır. Bir başka araştırmaya göre, mağdurlar, mobbing davranışlardan kaçınma yolları olarak daha özenli-yoğun çalışma, organize olma, üstü ile yüz yüze konuşmayı tercih etmektedirler (Yıldırım ve Yıldırım, 2006). Koç ve 
Bulut'a (2009) göre ise mağdurlar istifa etme, işten çıkarılma, sorunu bilmezden gelme ve bu durumu üst yönetim iletme gibi yöntemleri kullanmaktadırlar. Bunun yanında Samancı'ya (2001) göre, mağdurlar mobbingi, kabul etmekte, şikâyet konusu yapmamakta ve çatışmadan kaçınmayı tercih etmektedirler. Ulaşılan alanyazın ve bu araştırmanın sonuçları dikkate alındığında mobbing mağdurlarının, baş etme yöntemlerini etkili kullanamadıklarını göstermektedir, bu sonucun nedeni de çalışanların çatışma çözme yöntemlerini bilmemesi, hukuksal mücadele yollarının yeterince açık olmaması veya psikolojik şiddeti önleyen yasaların henüz var olmaması olabilir.

$\mathrm{Bu}$ araştırma bulgularına göre, mobbing sonucu bireysel, ailevi ve örgütsel olumsuz etkiler yaşanmaktadır. Bir başka araştırmaya göre, mobbing sonucu; yorgunluk, stres, iştah kaybı ve baş ağrısı gibi fiziksel bozukluklar ve psikolojik rahatsızlıklar görülmektedir (Yıldırım ve Yıldırım, 2006). Koç ve Bulut'a (2009) göre mobbing sonucu, istifa etme ve işten çıkarılma gibi olumsuz etkiler yaşanmıştır. Bir başka araştırmanın sonucuna göre, mağdurlarda, endişe hali, depresyon ve psikosomatik şikayetler gelişmektedir (Tınaz, 2006). Mobbingin ailevi olumsuz etkisi konusunda, Samanc1 (2001) iş yerinde baskı sonucu tedavi gören birçok hasta bulunduğunu ve işyerinde yaşanılan sıkıntıların, aile ilişkilerinin bozulmasına neden olduğunu belirtmektedir. Mobbingin örgütsel olumsuz etkisi konusunda, Tolan (1981), mobbingin mağduru, tüm örgütsel kural ve süreçlere karşı yabancılaştırdığını, mağdurun yaratıcılıklarını azalttığını, motivasyonunu düşürdüğünü, kuşkulu, sinirli, güvensiz bir hale getirdiğini, belirtmektedir. Araştırmalar, tıbbi olumsuz etkiler konusunda depresyon, kaygı, düşük motivasyon, konsantrasyon bozukluğu, obsesyon, suçluluk duygusu ve stres bozukluğu gibi rahatsızlıklar yaşand1ğını belirtmektedirler (Tolan, 1981; Zapf, 1999).
İlgili alanyazındaki bazı araştırmalara ve bu çalışmadaki bulgulara göre mobbing mağdurlarının, mobbingin üstesinden gelemedikleri için beden ve ruh sağlıklarında ağır sonuçlar yaşadıkları görülmektedir. Bunun da örgütün verimliliğinin düşmesinde önemli bir etken olduğu söylenebilir.

\section{Sonuç}

Bu çalışmada, eğitim kurumlarında karşılaşılan mobbing (yıldırma) uygulamalarına ilişkin mağdurların görüşleri belirlenmeye çalışılmış ve bu süreçte yaşadıkları sorunlar incelenmiştir. Bu çalışmadan elde edilen temel bulgu, mağdurların, mobbing sürecinin temel noktaları açısından benzer bakış açısına sahip olduklarıdır. Ancak alt temalar açısından mobbing mağdurlarının görüşlerinin çeşitlilik gösterdiği görülmektedir.

Mobbing mağdurlarının mobbingin nedenlerine ilişkin verdikleri yanıtlar, kendilerine, kuruma-ortama ve mobbingi uygulayana bağlı nedenler olarak sınıflanmıştır. Mobbing uygulamalarının türleri ise iletişim oluşumunu engelleme ile sosyal ilişkilere, itibara, mesleki durumuna ve sağlığa saldırılar olarak sınıflanmıştır. Mobbing mağdurlarının mobbing uygulamalarıyla baş etme yöntemlerine ilişkin yanıtları bireysel baş etme, hukuksal mücadele ve farkındalık geliştirme, olarak sınıflanmıştır. Mobbing mağdurlarının mobbing uygulamalarının olumsuz etkilerine ilişkin verdiği yanıtlar da bireysel, ailevi ve örgütsel olumsuz etkisi, olarak sınıflanmıştır. Bireysel etkiden toplumsal bir zarara kadar salgın halini alabilen mobbingin önlenmesi ve "bir insan hakkı ihlali" olan suçun işlenmemesi için bu araştırma bulguları doğrultusundaki öneriler şunlardır:

1-Mobbing sonucu bireyin maruz kalacağ zararların azaltılması ve bu süreci atlatıp geleceğe daha sağlıklı ulaşabilmesi amacıyla psikolojik destek sağlanması, hukuksal mücadele 
yollarının açılması ve kişisel gelişim yolları desteklenebilir.

2-Örgütsel baş etme yolları olarak;

-mobbingi ortadan kaldıracak paylaşımcı bir örgüt kültürü geliştirilebilir.

-insan kaynağının doğru ve etkin kullanımı açısından mobbingin kurumsallaşmasına engel olunacak ve mobbing mağdurlarına psikolojik destek verecek birimler kurulabilir,

-örgüt yapılanmasındaki (yatay ve dikey) süreçler belirlenip görev tanımları ve nesnel bir işbölümü yapılabilir,

3-Toplumsal baş etme yolları olarak; toplumsal farkındalık geliştirilmesi, sağlık kurumlarında “danışma ve destek birimleri" oluşturulması, moberleri cezalandıracak, caydıracak yasalar. gibi hukuksal düzenlemelerin yapılması, sendikalar, vakıflar ve meslek örgütlerinin, insan kaynakları bölümlerinin, yöneticilerin ve çalışanların, mobbing konusunda bilinçlendirilmesi sağlanabilir.

4. Mobbingi engelleme konusunda, eğitim, yönetim, sağlik, psikoloji ve hukuk gibi alanlarda disiplinler arası çalışmalar yapılabilir.

5. Mobbing hakkında daha zengin açıklamalar yapabilmek için benzer araştırmalar, farklı kurumları kapsayacak ve farklı araştırma yöntemlerini kullanacak biçimde gerçekleştirilebilir.

\section{Kaynakça}

Agervold, M. (2007). Bullying at Work: a Discussion of Definitions and Prevalence, Based on an Empirical Study, Scandinavian Journal of Psychology. 48, 161-172

Aquino K. and Byron K. (2002). Dominating Interpersonal Behavior and Perceived Victimization in Groups: Evidende for a Curvilinear Relationship, Journal of Management, 28 (1),69-87.

Akı, I. (2006). İşyerindeki Stresin Gizli Kaynağı: Zorbalık ve Duygusal Taciz. http://bilgipasajı.com. adresinden erişildi.

Browne, M. N. and Smith, M. A. (2008). Mobbing In the Workplace: The Latest Illlustration of Pervasive Individualism in American Law, Employee Rights and Employment Policy Journal, 12, 131-161

Büyüköztürk, Ş., Çakmak, E. K., Akgün, Ö. E., Karadeniz, Ş. ve Demirel, F. (2009). Örnekleme Yöntemleri Bilimsel Araştırma Yöntemleri Kitabı Sunusu,

http://msbay.files.wordpress.com/2009/10/9-hafta-arastirmalarda-ornekleme.pdf adresinden erişildi.

Cemaloğlu, N. ve Ertürk, A. (2008). Öğretmen ve Okul Müdürlerinin Maruz Kaldıkları Yıldırmanın Yönü. Ahmet Yesevi Üniversitesi Mütevelli Heyet Başkanlığı, Bilig Dergisi. 46, 67-86

Cemaloğlu, N. ve Kılınç, A. Ç. (2012). İlköğretim Okulu Yöneticilerinin Etik Liderlik Davranışları ile Öğretmenlerin Algıladıkları Örgütsel Güven ve Yıldırma Arasındaki İlişki. Eğitim ve Bilim. 37 (165). 137-151

Çalışkan, O. (2005). Turizm İşletmelerinde Çalışanlara Yapılan Yıldırma Davranışları. Yayınlanmamış Yükseklisans Tezi. Mersin Üniversitesi, Sosyal Bilimler Enstitüsü. Mersin.

Çobanoğlu, Ş. (2005). Mobbing; İşyerinde Duygusal Saldırı ve Mücadele Yöntemleri. Timaş Yayınları Psikoloji Dizisi, 34-35

Einarsen, S. (1999). The Nature and Causes of Bullying at Work. International Journal of Manpower, 20 (1/2), 16-27.

Eser, O. (2006). Mobbing Kavramının Türkçe Serüveni. http://turkoloji.cu.edu.tr/YENI\%20TURK \%20DILI/oktay_eser_mobbing_kavrami.pdf adresinden erişildi. 
Koç, M. ve Bulut, H. U. (2009). Ortaöğretim Öğretmenlerinde Mobbing: Cinsiyet Yaş ve Lise Türü Değişkenleri Açısından İncelenmesi. International Online Journal of Educational Sciences, 1 (1), 64 - 80

Kök, S. B. (2006). İş Yaşamında Psiko-Şiddet Sarmalı Olarak Yıldırma Olgusu ve Nedenleri. Sosyal Bilimler Enstitüsü Dergisi. 13, 434-448

Leymann, H. (1996). The Content and Development of Mobbing at Work, Europen Journal of Work and Organizational Psychology, 5 (2), 165-184.

Leymann, H. (2000). What is PTSD? The Mobbing Encyclopedia. http://www.leymann.se/English/15100E.HTM. adresinden erişildi.

Mercan, N. (2007). Örgütlerde Mobbing'in Örgüt İklimiyle İlişkisine Yönelik Bir Araştırma Yayımlanmamış yüksek lisans tezi. Dumlupınar Üniversitesi, Sosyal Bilimler Enstitüsü, İşletme Anabilim Dalı. Kütahya.

Ocak, S. (2008). Öğretmenlerin Duygusal Tacize (Mobbinge) İlişkin Algıları (Edirne İli Örneği). Yayımlanmamış Yüksek Lisans Tezi. Trakya Üniversitesi. Sosyal Bilimler Enstitüsü Eğitim Bilimleri Anabilim Dalı, Eğitim Yönetimi, Teftişi, Planlaması ve Ekonomisi Bilim Dalı. Edirne

O'Moore, M. and etc, (2003). The Rates and Relative Risks of Workplace Bullying in Ireland a Country of High Economic Growth, International Journal Management and Decision Making, 4 (1), 82-95.

Otrar, M. ve Özen, B. (2009). Rehber Öğretmenlerin Okul Ortamında Algıladıkları Yıldırma Davranışları. İş Ahlakı Dergisi. 2 (3), 97-120,

Özturk H., Sökmen S., Yılmaz, F. ve Çilingir, D. (2007). Measuring Mobbing Experiences of Academic Nurses: Development of a Mobbing Scale", American Academy of Nurse Practitioner, 439-443

Samanc1, A. Y. (2001) Taciz, depresyon, istifa... (in Turkish). www.radikal.com/tr/2001/01/22/yasam/01tac.shtml adresinden erişildi.

$\begin{array}{lllll}\text { Tarhan, N. (2004). Psikolojik } & \text { Savaş; } & \text { Yıldırma }\end{array}$ www.ailem.com/templates/news/detail/detail11.asp?id=6801 adresinden erişildi.

Tigrel, E. Y. ve Kokalan, O. (2009). Academic Mobbing in Turkey. International Journal of Human and Social Sciences. 4 (10). 716-724

Tınaz, P. (2006). İsyerlerinde Psikolojik Taciz (Mobbing). Beta Basım Yayım: İstanbul.

Timmerman G. and Bajeme C. (2000). The Impact of Organizational Culture on Perceptions and Experiences of Sexual Harassment, Journal of Vocational Behavior, 57, 188-205.

Tolan, B. (1981). Çağdaş Toplumun Bunalımı: Anomi ve Yabancılaşma. Ankara: İktisadi ve Ticari İlimleri Akademisi Yayınları.

Tutar, H. (2004). İşyerinde Psikolojik Şiddet Sarmalı: Nedenleri ve Sonuçları. Yönetim Bilimleri Dergisi. 2 (2), 101-128

Türnüklü, A. (2000). Eğitim Bilim Araştırmalarında Etkin Olarak Kullanılabilecek Nitel Araştırma Tekniği: Görüşme. Kuram ve Uygulamada Ĕ̆itim Yönetimi, 24, 543-559

Ünver, G., Bümen, N. T. ve Başbay, M. (2010). Ortaöğretim Alan Öğretmenliği Tezsiz Yüksek Lisans Derslerine Öğretim Elemanı Bakışı: Ege Üniversitesi Örneği. Eğitim ve Bilim Dergisi, 155 (35), 6377.

Yıldırım, A. ve Şimşek, H. (2003). Sosyal Bilimlerde Nitel Araştırma Yöntemleri. Ankara: Seçkin Yayınları

Yildırım, A. ve Yildırım, D. (2006). Mobbing in the Workplace by Peers and Managers: Mobbing Experienced by Nurses Working in Healthcare Facilities in Turkey and its Effect on Nurses, In Clinical Nursing Journal of Clinical Nursing, 1144-1149

Yılmaz, A., Özler, D. E. ve Mercan, N. (2008). Mobbing ve Örgüt İklimi ile İlişkisine Yönelik Ampirik Bir Araştırma. Elektronik Sosyal Bilimler Dergisi. 7 (26), 334-357. 
Yılmaz, K. ve Altınkurt, Y. (2011). Göreve Yeni Başlayan Özel Dershane Öğretmenlerinin Kurumlarındaki Çalışma Koşullarına İlişkin Görüşleri. Kuram ve Uygulamada Eğitim Bilimleri, 11 (2), 635-650.

Yücetürk, E. E. (2003). Bilgi Çağında Örgütlerin Görünmeyen Yüzü: Mobbing, http://www.bilgiyonetimi.org. adresinden erişildi.

Zapf, D. (1999). Organisational, Work, Group Related and Personal Causes of Mobbing/Bullying at Work, International Journal of Manpower, 20 (1/2), 70-85

\section{Extended Abstract}

Mobbing creates many negative results in terms of both organizations and staff. Mobbing is becoming a major social problem as it engenders a business life where happy individuals and labor peace do not exist. In this context; it is of utmost important to have awareness, to determine causes, and measures of this phenomenon, which can lead to serious negative results at the individual and organizational and even social level. In educational institutions, there are only a limited number of studies carried on mobbing as an obstacle for healthy business life in organizations. This study tries to make a realistic assessment about practices of mobbing and offers precautions against them. With this study it is expected to contribute to the field by filling this important gap. In this sense, the aim of the research is to determine mobbing implications encountered in educational institutions and to develop some possible recommendations for future studies in the light of findings.

This study is a qualitative research and a semi structured interview is used. Participants are composed of instructors working in different education institutions. Purposive sampling method is used in the study. Draft of the semi structured interview form gets the final form through with the expert opinions. In the study, internal validity is obtained by examining of experts, confirmation of participants and making the interviews in a long time interval. External validity is obtained by detailed description. Also, by consistency examining, internal reliability is obtained and by confirmation examination made by three experts, external reliability is obtained. For the data analysis, descriptive and content analysis methods are used.

According to the views related to the causes of mobbing, the participants mentioned similar opinions: for individual reasons such as career promotion, intellectual knowledge, value system, openness to development, ignorance about mobbing, social personality, etc.; for institutional-environmental reasons: such as having financial gain, management style-weak leadership, negative corporate culture, etc.; for the reasons related to mobbing practitioners: such as mobber's being addicted to power, authoritarian, competitive, prejudice, lacking professional skills in the field, feeling the need to enhance the prestige, etc..

According to the views on types of mobbing implications, the participants mentioned similar opinions which can be grouped as blocking communication such as yell, sarcasm, scolding, insults, restriction and etc.; an attack to social relations such as blocking social communications due to grouping of mobbing practitioners, exclusion, to hurt and to ignore friends etc.; an attack on reputation such as to reduce the reputation, to propagate rumors, to slander, to act like a mental patient, make fun of and so forth; an attack to professional status such as relocation, obscuring access to the authorities, not assigning, damaging personal belongings etc.; an attack to health such as increasing the workload, physical violence and threats and so on.

According to the views on methods of coping with mobbing, participants mentioned similar opinions about individual strategies such as sharing, avoidance, psychological support, concealment, a request for assistance from the group, personal development etc., the legal struggle: such as suing, complaining to the upper management and data collection and awareness-developing and so on. According to the 
views of the adverse effects of mobbing practices, the participants mentioned similar opinions about individual effects: such as physical harm, psychological impact, stress, economic damage etc.; family effects: such as affects to children, family conflict and family peace and so forth.; organizational effects: such as getting permission, low job quality, legal action / lawsuit costs, early retirement, declining of institutional prestige, infected institutions etc.

According to victims of mobbing, themes of causes of mobbing were personal, institutionalenvironment causes and causes about mobbing practitioners. Types of mobbing were determined as attacking to social relations with blocking the formation of communication, attacking to reputation, attacking to professional situation, and attacking to personal healty. According to victims of mobbing the ways of coping with mobbing were the ways of individual coping with, the ways of legal struggle, and the way of developing of awareness. The victims of mobbing expressed that effects of negative of mobbing were individual effects, familiar effects and organizational effects.

The findings of this study and literature reveal that the causes of mobbing have not been resolved effectively by managers. Mobbing practitioners use together many methods to achieve their goal. Using various mobbing methods easily may indicate that a transparent management and effective supervision structure have not been established and awareness about mobbing has not developed either. It is observed that victims of mobbing experience severe mental and physical health problems as a consequence of not being able to apply effective methods for coping with mobbing. It can be said that this finding is an important factor in decrease of the efficiency of the organization as well.

In this study, views of victims subject to mobbing implications in educational institutions are identified and problems encountered by these victims in the mobbing process are investigated. The main finding of this study shows that the views of victims of mobbing have similarities in terms of the main points of mobbing. However, these views of victims of mobbing display certain diversity in terms of sub-themes. Mobbing implications have harmfull effects both individual and social. Because mobbing can get the situation of epidemic, mobbing must block and not commit. Thus mobbing is violation of human right. This research has some suggestions in line with results of research. In order to the fact that individuals subject to mobbing should be decreased their damages and have healty life psychological support should be provided, legal ways for combating should be open, the ways of personal development should be supported. As the ways of organizational coping: there should be developed a sharing organizatonal culture to remove the mobbing; in terms of the usage of true and operative of source of people, some units should be structured, this units should block the institualizations of mobbing and give psychological support; processes (horizontal and vertical) in structure of organizational should be determined and definitions of task and the division of labor should be made subjective. As the ways of social coping: the social awareness should be developed, counseling and support units should be structure in health institutions, legal regulations to punish the mobbing practitioners should be preparations, trade unions, foundations and professional organizations, departments of human resources, managers and employees should be achieved awareness about mobbing. Interdisciplinary researches should be made in some departments such as education, administration, health, psychology and legal on the blocking of mobbing. Different institutions covering and different researches tecniques using similar researches should be carried out for deeper explanations about mobbing. 